Japanese Journal of Physiology, 35, 311-320, 1985

\title{
Effects of Intraventricular Neurotensin on Blood Pressure and Heat Balance in Rats
}

\author{
Osamu SHIDo and Tetsuo NAgaSAKa \\ Department of Physiology, School of Medicine, Kanazawa University, \\ Kanazawa, 920 Japan
}

\begin{abstract}
The effects of intraventricular neurotensin (NT) at doses of $0.1,1.0$, and $10.0 \mu \mathrm{g}$ on blood pressure (BP), heart rate (HR), heat production $(M)$, heat loss $(H)$, and colonic temperature $\left(T_{\mathrm{co} 1}\right)$ were investigated in conscious rats in a direct calorimeter at 18 and $28^{\circ} \mathrm{C}$. At $18^{\circ} \mathrm{C}$, a $10.0 \mu \mathrm{g}$ of NT significantly increased BP for several minutes after injection with prolonged bradycardia. The larger two doses (1.0 and $10.0 \mu \mathrm{g}$ ) significantly reduced $M$ and $T_{\mathrm{col}}$. In sinoaortic denervated rats, a $1.0 \mu \mathrm{g}$ of NT elevated BP and decreased HR. The decrease in HR was significantly smaller than that in nerve intact rats, which indicates the occurrence of baroreflex with intraventricular NT. The changes in $M$ and $T_{\mathrm{col}}$ in the denervated rats were, however, not statistically different from the intact rats. The baroreflexive suppression of metabolism seems to play a minimum role in the NT-induced hypothermia. $H$ slightly increased for several minutes after central NT (1.0 and $10.0 \mu \mathrm{g})$ and significantly decreased thereafter. Thermal conductance significantly increased for a longer period of time after NT injection. At $28^{\circ} \mathrm{C}$, $1.0 \mu \mathrm{g}$ of NT increased $H$ and $M$. It is concluded that central NT produced hypothermia by reducing $M$ and enhancing $H$ in the cool environment, but not at $28^{\circ} \mathrm{C}$.
\end{abstract}

Key words: neurotensin, baroreflex, heat production, heat loss, hypothermia.

Centrally injected neurotensin (NT) has been known to have a profound effect on body temperature in various animals. In rodents and monkeys, NT injected into the cerebroventricle produces dose-dependent hypothermia especially in cold environment (BISSETTE et al., 1976, 1982; BROWN and MilleR, 1982; LeE and MYers, 1983; MARTIN et al., 1980; NEMEROFF et al., 1977, 1980), and metabolic reduction seems to play an important role in developing this hypothermia (ChANDRA et al., 1981; MoRA et al., 1984). Intraventricular NT has also been known to affect the cardiovascular system of mammals, although the results

Received for publication November 16,1984

紫藤 治, 永坂鉄夫 
remain controversial (Rioux et al., 1981; SumNERS et al., 1982). SumNers et al. (1982) observed that NT injected centrally caused an immediate and dose-dependent rise in blood pressure in conscious rats. Since several investigators observed that the arterial baroreflex following a rise in the systemic blood pressure suppressed shivering and nonshivering thermogenesis in conscious animals in cold environment (Hohtola et al., 1980; NunOMURA, 1983; Shibata, 1982; ShIDo et al., 1984; WASSERSTRUM and HERD, 1977), the possibility exists that the baroreflex could contribute to hypothermia following intraventricular NT. Therefore, we attempted to examine the contribution of baroreceptor-mediated metabolic reduction to the NT-induced hypothermia in conscious rats at an ambient temperature of $18^{\circ} \mathrm{C}$. The effect of intraventricular NT on heat loss mechanisms has not been established. Cutaneous vasodilation was suggested following central injection of NT in conscious monkeys (MORA et al., 1984), but CHANDRA et al. (1981) reported vasoconstriction in conscious rats. We also investigated the heat loss response to central NT with direct calorimetory in conscious rats at 18 and $28^{\circ} \mathrm{C}$.

\section{METHODS}

Animals and preparations. Male Wistar rats, initially weighing 280-320 g, were used. They were housed individually in rat cages in an animal room at $24 \pm$ $1^{\circ} \mathrm{C}$ with a 12:12 LD cycle and were provided laboratory rat chow and tap water ad libitum. In all rats, a 22-gauge stainless steel cannula was stereotaxically implanted into the left lateral ventricle under pentobarbital sodium $\left(50 \mathrm{mg} \cdot \mathrm{kg}^{-1}\right.$, i.p.) anesthesia. The location of the cannula was confirmed by the spontaneous flow of cerebrospinal fluid from the cannula. Thereafter, a steel stylet was inserted into the cannula to prevent obstruction. From 2 days after surgery, the rats were loosely restrained in a cylindrical wire mesh cage for $4 \mathrm{hr}$ almost every day for over 8 days to get them accustomed to the experimental situations. After the acclimation period, the rats underwent a second operation under pentobarbital anesthesia. A polyethylene catheter (o.d. $0.6 \mathrm{~mm}$, i.d. $0.3 \mathrm{~mm}$ ) filled with heparinized saline for measuring the mean arterial blood pressure (BP) was inserted into the abdominal aorta via the right femoral artery, tunnelled subcutaneously and brought out through the back skin of the neck thereafter. Additionally in 4 rats, sinoaortic deafferentation (KRIEGER, 1964) was performed with a longitudinal cervical incision. One day after the second surgery, the rats were used in the experiment. After all experiments, the rats were sacrificed with a large dose of anesthetics for gross examination of the location of the ventricular cannula.

Measurements. On the day of the experiment, rats were loosely restrained in the cylindrical wire mesh cage. A thermister probe was inserted $6 \mathrm{~cm}$ into the colon and fixed with vinyl tape, and 4 copper wire electorodes were fixed on the chest of rats. A stainless steel injection needle connected by a polyethylene tube 
containing NT solution was inserted $0.5 \mathrm{~mm}$ beyond the tip of the ventricular cannula. To avoid the diffusion of the drug from the needle into the ventricle, a very fine air bubble had been sucked inside the needle. A vinyl chloride pan filled with vegetable oil was set underneath the rat cage to collect their urine and feces to avoid the evaporations from the wastes. After these manipulations were over, rats in cages were transferred into a direct calorimeter sized $12 \times 23 \times 12 \mathrm{~cm}$ (NAGASAKA et al., 1979). The ambient temperature $\left(T_{\mathrm{a}}\right)$ had been chosen to be either 18 or $28 \pm 0.02^{\circ} \mathrm{C}$, and the temperature controlled dry air $\left(2 l \cdot \mathrm{min}^{-1}\right)$ was introduced into the calorimeter.

BP was monitored with a pressure transducer (MPU-0.5, Toyo Baldwin, Tokyo) via the arterial catheter, and heart rate (HR) was counted every 2 min from the ECG recordings. Oxygen consumption was measured with a Beckman $\mathrm{O}_{2}$ analyzer (Model 755, USA) and the rate of heat production $\left(M: \mathrm{W} \cdot \mathrm{m}^{-2}\right)$ was calculated as $\mathrm{RQ}=0.83$. Colonic temperature $\left(T_{\text {col }}\right)$ was measured with the thermistor. Dry heat loss $(R+C)$ was measured with the direct calorimeter and evaporative heat loss $(E)$ was monitored with a humidity sensor (HMI-11, Vaisala, Helsinki), and both were calculated as $\mathrm{W} \cdot \mathrm{m}^{-2}$. All variables except HR were continuously recorded on potentiometers (MC 6735, Watanabe Sokki, Tokyo; SP-H6P, Riken Denshi, Tokyo). After the records had been stabilized for 90 $\min , 0.1,1.0$, or $10 \mu \mathrm{g}$ of NT (Peptide Institute Protein Research Foundation, Osaka) dissolved in $3 \mu \mathrm{l}$ saline was injected into the left lateral ventricle of rats. The measurements continued for the following $60 \mathrm{~min}$. The rats received only one dose of NT and were not repeatedly used in experiments.

Statistics. The results are presented as the mean \pm S.E. Statistical evaluations of the data was performed by a one-way analysis of variance, and the statistical significance of difference between mean values was assessed by paired or unparied Student's $t$-test. The level of significance was set at $p<0.05$.

\section{RESULTS}

Tables 1 and 2 summarize the mean resting values and the maximal responses of BP, HR, $T_{\mathrm{col}}, M$, total heat loss $(H),(R+C)$, and $E$ to the intraventricular $\mathrm{NT}$ at $0.1,1.0$, and $10.0 \mu \mathrm{g}$ at $18^{\circ} \mathrm{C}$. Intraventricular saline $(3 \mu \mathrm{l})$ produced no significant change in any variables and the results were abbreviated. Figure 1 shows the changes of $\mathrm{BP}$ and $\mathrm{HR}$ at $18^{\circ} \mathrm{C}$. The 1.0 and $10.0 \mu \mathrm{g}$ of NT produced an immediate rise in BP, but the rise was significant only for the period from 6 to $12 \mathrm{~min}$ after injection of the $10.0 \mu \mathrm{g}$ of NT. The $0.1 \mu \mathrm{g}$ of NT did not affect BP. Both the 1.0 and $10.0 \mu \mathrm{g}$ of NT produced a significant and long-lasting bradycardia. The $0.1 \mu \mathrm{g}$ of NT did not again affect HR. Figure 2 shows the changes in $T_{\text {col }}, M$, and $H$ following NT injection at $18^{\circ} \mathrm{C}$. The $10.0 \mu \mathrm{g}$ of NT produced a significant hypothermia with a marked reduction of $M$. The fall in $T_{\text {col }}$ was over $2.0^{\circ} \mathrm{C}$, and the period of hypothermia clearly continued for over 
60 min. The period of reduction in $M$ continued for 40 min with the maximal metabolic suppression of $30 \mathrm{~W} \cdot \mathrm{m}^{-2}$ at approximately $30 \mathrm{~min}$ after the NT injection. $H$ slightly increased for the first $20 \mathrm{~min}$ and significantly decreased there-

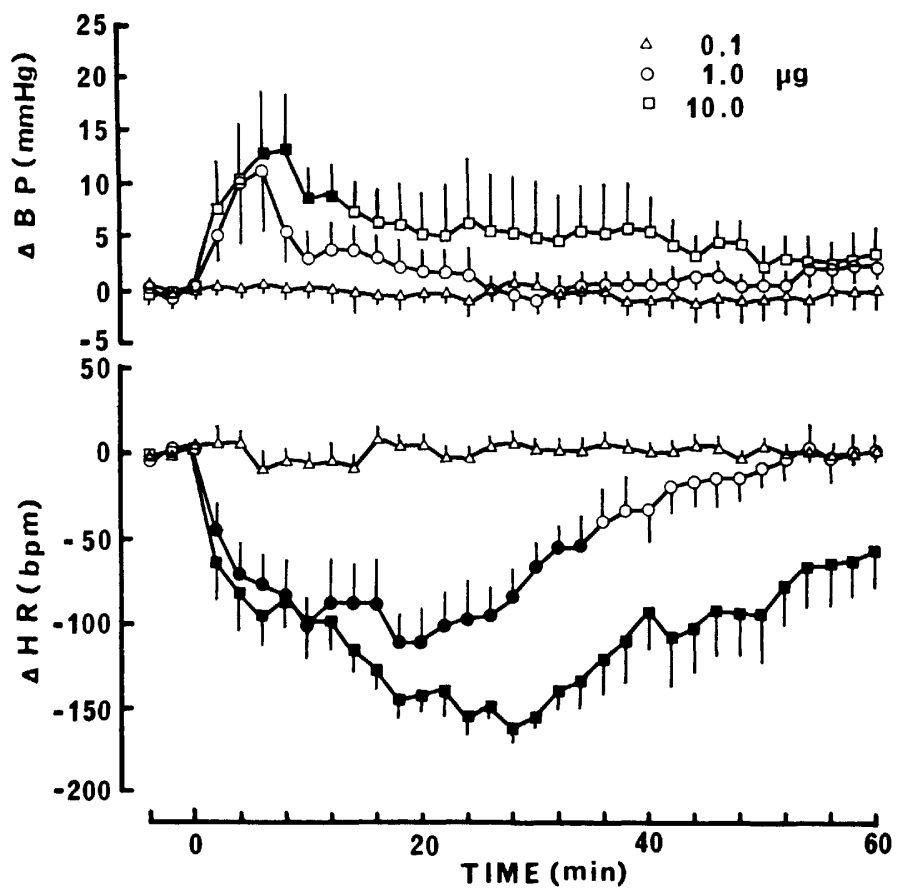

Fig. 1. Changes in mean blood pressure $(\Delta \mathrm{BP})$ and heart rate $(\Delta \mathrm{HR})$ from resting levels following various doses of NT injection into lateral ventricle. Values are means and vertical bars are S.E. Time 0 indicates the time of NT injection. Triangles, at dose of $0.1 \mu \mathrm{g}$ of NT; circles, at dose of $1.0 \mu \mathrm{g}$; squares, at dose of $10.0 \mu \mathrm{g}$. Black symbols, significantly different from resting values.

Table 1. Resting values of mean blood pressure (BP), heart rate (HR), colonic temperature $\left(T_{\mathrm{col}}\right)$, metabolic rate $(M)$, total heat loss $(H)$, dry heat loss $(R+C)$, and evaporative heat loss $(E)$ at $18^{\circ} \mathrm{C}$.

\begin{tabular}{ccccrrrr}
\hline $\begin{array}{c}\text { Dose } \\
(\mu \mathrm{g})\end{array}$ & $\begin{array}{c}\mathrm{BP} \\
(\mathrm{mmHg})\end{array}$ & $\begin{array}{c}\mathrm{HR} \\
(\mathrm{bpm})\end{array}$ & $\begin{array}{c}T_{\mathrm{col}} \\
\left({ }^{\circ} \mathrm{C}\right)\end{array}$ & $\begin{array}{c}M \\
\left(\mathrm{~W} \cdot \mathrm{m}^{-2}\right)\end{array}$ & $\begin{array}{c}H \\
\left(\mathrm{~W} \cdot \mathrm{m}^{-2}\right)\end{array}$ & $\begin{array}{c}R+C \\
\left(\mathrm{~W} \cdot \mathrm{m}^{-2}\right)\end{array}$ & $\begin{array}{c}E \\
\left(\mathrm{~W} \cdot \mathrm{m}^{-2}\right)\end{array}$ \\
\hline 0.1 & 125.1 & 485.3 & 37.20 & 95.2 & 97.1 & 85.0 & 12.1 \\
$(n=6)$ & \pm 0.8 & \pm 6.8 & \pm 0.14 & \pm 2.9 & \pm 2.6 & \pm 1.7 & \pm 1.3 \\
1.0 & 123.7 & 458.1 & 37.21 & 91.9 & 94.5 & 84.7 & 9.7 \\
$(n=7)$ & \pm 2.4 & \pm 12.7 & \pm 0.27 & \pm 3.8 & \pm 1.3 & \pm 1.3 & \pm 0.4 \\
10.0 & 123.7 & 482.6 & 37.26 & 94.4 & 94.4 & 85.7 & 8.6 \\
$(n=7)$ & \pm 2.8 & \pm 7.0 & \pm 0.17 & \pm 2.8 & \pm 2.5 & \pm 2.2 & \pm 0.4 \\
\hline
\end{tabular}

Values (mean \pm S.E.) were obtained as the means of three data sets before NT injection. The numbers in parentheses indicate the numbers of rats. 
Table 2. Maximal changes of mean blood pressure ( $\triangle \mathrm{BP})$, heart rate ( $\Delta \mathrm{HR})$, colonic temperature $\left(\Delta T_{\mathrm{col}}\right)$, metabolic rate $(\Delta M)$, total heat loss $(\Delta H)$, dry heat loss $(\Delta(R+C))$, and evaporative heat loss $(\Delta E)$ following various doses of NT injection into lateral ventricle at $18^{\circ} \mathrm{C}$.

\begin{tabular}{cccccccc}
\hline $\begin{array}{c}\text { Dose } \\
(\mu \mathrm{g})\end{array}$ & $\begin{array}{c}\Delta \mathrm{BP} \\
(\mathrm{mmHg})\end{array}$ & $\begin{array}{c}\Delta \mathrm{HR} \\
(\mathrm{bpm})\end{array}$ & $\begin{array}{l}\Delta T_{\mathrm{col}} \\
\left({ }^{\circ} \mathrm{C}\right)\end{array}$ & $\begin{array}{c}\Delta M \\
\left(\mathrm{~W} \cdot \mathrm{m}^{-2}\right)\end{array}$ & $\begin{array}{c}\Delta H \\
\left(\mathrm{~W} \cdot \mathrm{m}^{-2}\right)\end{array}$ & $\begin{array}{c}\Delta(R+C) \\
\left(\mathrm{W} \cdot \mathrm{m}^{-2}\right)\end{array}$ & $\begin{array}{c}\Delta E \\
\left(\mathrm{~W} \cdot \mathrm{m}^{-2}\right)\end{array}$ \\
\hline 0.1 & $\mathrm{~ns}$ & $\mathrm{~ns}$ & $\mathrm{~ns}$ & $\mathrm{~ns}$ & $\mathrm{~ns}$ & $\mathrm{~ns}$ & $\mathrm{~ns}$ \\
$(n=6)$ & & & & & & & \\
1.0 & $\mathrm{~ns}$ & -125.9 & -1.48 & -31.5 & -10.8 & -9.6 & $\mathrm{~ns}$ \\
$(n=7)$ & & \pm 17.1 & \pm 0.25 & \pm 4.5 & \pm 1.1 & \pm 1.1 & \\
10.0 & +15.4 & $-179.0^{*}$ & $-2.54^{*}$ & -40.0 & -11.4 & -12.2 & $\mathrm{~ns}$ \\
$(n=7)$ & \pm 5.3 & \pm 7.0 & \pm 0.29 & \pm 4.2 & \pm 2.6 & \pm 2.3 & \\
\hline
\end{tabular}

Values (mean \pm S.E.) are the maximum changes within 60 min after NT injection.

* Significantly different from $1.0 \mu \mathrm{g}$ of NT injected group. ns, no significant change.
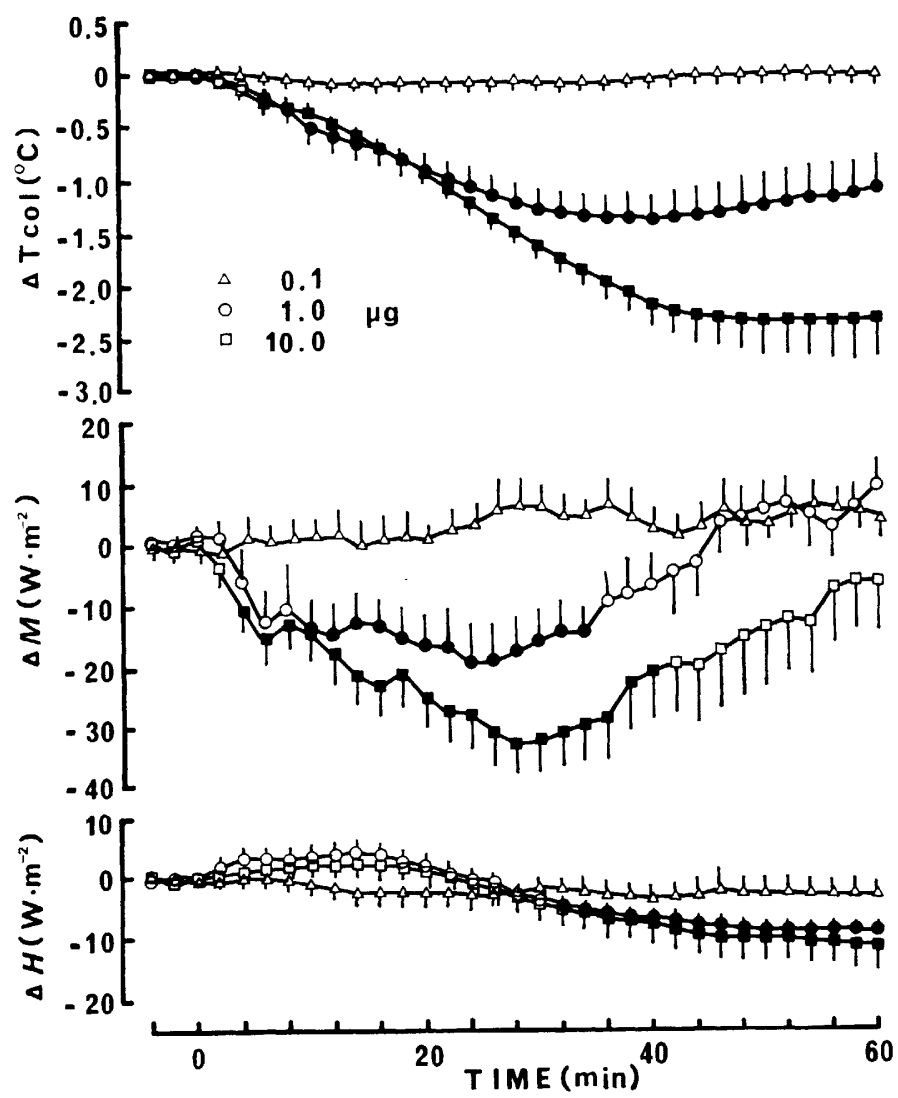

Fig. 2. Changes in colonic temperature $\left(\Delta T_{\text {col }}\right)$, metabolic rate $(\Delta M)$, and total heat loss $(\Delta H)$ from resting levels following various doses of NT injection into lateral ventricle. Values are means and vertical bars are S.E. Time 0 indicates the time of NT injection. Symbols are the same in Fig. 1. 
Table 3. Resting values and the maximal changes following $1.0 \mu \mathrm{g}$ of intraventricular NT injection in mean blood pressure (BP), heart rate (HR), colonic temperature $\left(T_{\mathrm{co} 1}\right)$, metabolic rate $(M)$, total heat loss $(H)$, dry heat loss $(R+C)$, and evaporative heat loss $(E)$ in 4 sinoaortic denervated rats at $18^{\circ} \mathrm{C}$.

\begin{tabular}{lccccccc}
\hline & $\begin{array}{c}\mathrm{BP} \\
(\mathrm{mmHg})\end{array}$ & $\begin{array}{c}\mathrm{HR} \\
(\mathrm{bpm})\end{array}$ & $\begin{array}{l}T_{\mathrm{col}} \\
\left({ }^{\circ} \mathrm{C}\right)\end{array}$ & $\begin{array}{c}M \\
\left(\mathrm{~W} \cdot \mathrm{m}^{-2}\right)\end{array}$ & $\begin{array}{c}H \\
\left(\mathrm{~W} \cdot \mathrm{m}^{-2}\right)\end{array}$ & $\begin{array}{c}R+C \\
\left(\mathrm{~W} \cdot \mathrm{m}^{-2}\right)\end{array}$ & $\begin{array}{c}E \\
\left(\mathrm{~W} \cdot \mathrm{m}^{-2}\right)\end{array}$ \\
\hline Resting & $147.7^{*}$ & 493.4 & 36.71 & 95.6 & 93.4 & 81.6 & 11.8 \\
values & \pm 2.4 & \pm 10.5 & \pm 0.16 & \pm 2.6 & \pm 3.8 & \pm 3.2 & \pm 1.0 \\
Maximal & $+47.5^{*}$ & $-63.4^{*}$ & -1.36 & -29.9 & -9.9 & -9.3 & $\mathrm{~ns}$ \\
changes & \pm 4.1 & \pm 15.3 & \pm 0.19 & \pm 5.7 & \pm 3.1 & \pm 2.6 & \\
\hline
\end{tabular}

Values are mean \pm S.E. * Significantly different from $1.0 \mu \mathrm{g}$ of NT injected group in Tables 1 and 2 . ns, no significant change.

after. There was no significant change in $E$. The $1.0 \mu \mathrm{g}$ of NT produced similar changes in $T_{\text {col }}, M$, and $H$, although the magnitudes of the changes in $T_{\text {col }}$ and $M$ were evidently less. The maximum reduction of $M$ was $20 \mathrm{~W} \cdot \mathrm{m}^{-2}$ occurring approximately $25 \mathrm{~min}$ after the injection of NT. The $0.1 \mu \mathrm{g}$ of NT did not affect $T_{\text {co1 } 1}, M$, and $H$.

Table 3 summarizes the effects of sinoaortic denervation in the responses to an intraventricular injection of NT $(1.0 \mu \mathrm{g})$ at $T_{\mathrm{a}}$ of $18^{\circ} \mathrm{C}$. In the sinoaortic denervated rats $(n=4)$, the resting BP was significantly higher than that observed in the nerve intact control rats. In contrast to the insignificant increase in BP in the control rats, the vasopressor action of NT was significantly greater in the denervated rats. However, the reduction of $\mathrm{HR}$ was greatly suppressed, and the magnitude of decrease in HR was statistically significant. In the denervated rats, the $1.0 \mu \mathrm{g}$ NT significantly decreased $T_{\text {col }}, M$, and $H$. The maximum decreases in these parameters were approximately the same as those in the control rats.

An additional experiment was done at $28^{\circ} \mathrm{C}$ in another 7 rats. The $1.0 \mu \mathrm{g}$ of intraventricular NT produced a significant elevation of BP by $17.5 \mathrm{mmHg}$ but did not affect HR. The changes of $T_{\mathrm{eo} 1}$ after NT injection were various (hyperthermia was observed in 2 rats and hypothermia in 3 rats) and not statistically significant. $M, H,(R+C)$, and $E$ increased significantly following intraventricular administration of NT by $13.9,10.5,6.4$, and $4.1 \mathrm{~W} \cdot \mathrm{m}^{-2}$, respectively.

\section{DISCUSSION}

The intraventricularly injected NT at doses ranging from $1.0 \mu \mathrm{g}$ to $10.0 \mu \mathrm{g}$ elevated $\mathrm{BP}$ in conscious rats at 18 and $28^{\circ} \mathrm{C}$. The results supported the report of SUMNERS et al. (1982) who observed the dose-dependent rise in BP following NT injection. At $18^{\circ} \mathrm{C}$, the $1.0 \mu \mathrm{g}$ of central NT produced a significant decrease in HR by 125.9 beats per min (bpm) in the control rats. In the sinoaortic de- 
nervated rats, however, the same dose of NT decreased HR by only $63.4 \mathrm{bpm}$. About a half of the bradycardia following NT injections may be attributed to the sinoaortic baroreflex reduction of HR.

It has been shown that the baroreflex suppresses shivering and nonshivering thermogenesis of conscious animals in cool environments (HoHTOLA et al., 1980; Nunomura, 1983; Shibata, 1982; Shido et al., 1984; Wasserstrum and Herd, 1977). Recently, we observed that an intraventricular injection of angiotensin II produced a decrease in metabolism and a fall in body temperature with a concomitant rise in BP and bradycardia (SHIDo et al., 1985). Since hypothermia and metabolic suppression were markedly diminished in the sinoaortic denervated rats, the conclusion was that the hypothermic response to the central angiotensin II was attributed to the sinoaortic baroreflexive suppression of metabolism. Thus, if the central NT raises BP, it is possible that the NTinduced hypothermia is attributed to the baroreflex-mediated metabolic reduction. As shown in Tables 2 and 3, however, the maximum decreases in $M$ and $T_{\text {col }}$ after the $1.0 \mu \mathrm{g}$ of NT were the same in the control and the sinoaortic denervated rats, and the baroreflex seemed to play a minimum role in the NT-induced hy-

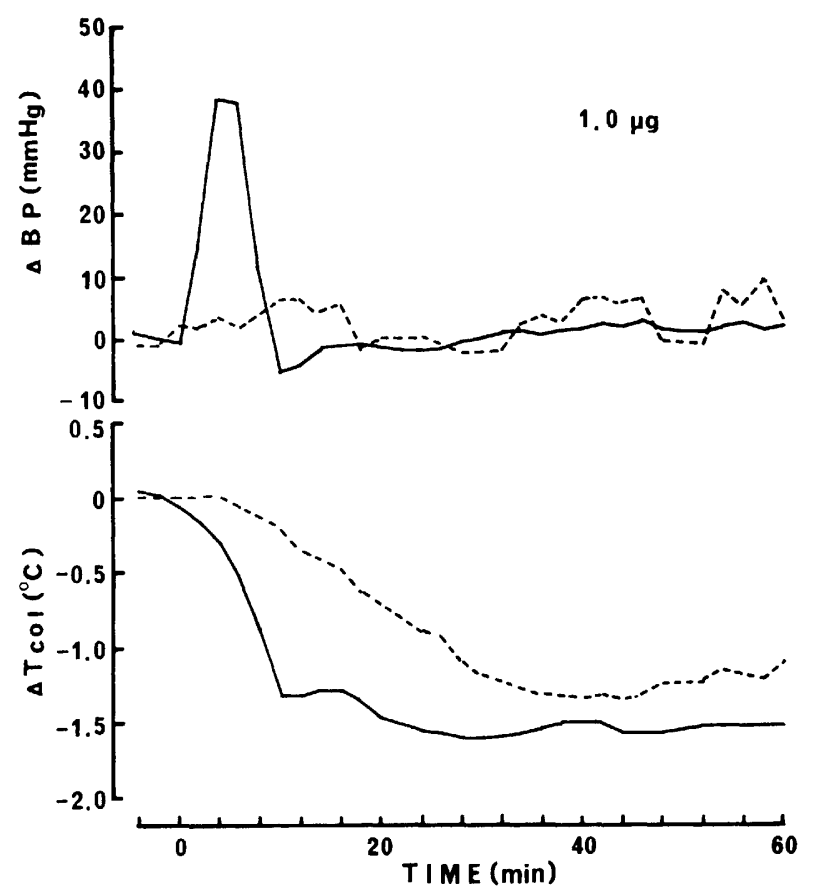

Fig. 3. Changes in mean blood pressure $(\Delta \mathrm{BP})$ and colonic temperature $\left(\Delta T_{\mathrm{co} 1}\right)$ from resting values following $1.0 \mu \mathrm{g}$ of NT injection into lateral ventricle in two examples. Solid lines and dotted lines show different examples. Time 0 indicates the time of NT injection. 
pothermia. The NT caused a rapid rise of BP which lasted only for a short period of time (Fig. 1) and it sometimes even failed to riase BP. Figure 3 illustrates two different examples of the responses to central NT $(1.0 \mu \mathrm{g})$ on $\mathrm{BP}$ and $T_{\mathrm{col}}$ at $18^{\circ} \mathrm{C}$. In one rat (shown as solid lines), a marked and sharp rise in BP and a rapid fall in $T_{\text {col }}$ were noticed. No such rapid changes in BP and $T_{\text {col }}$ were observed in the other rat (shown in dotted lines). The magnitudes of hypothermia of the two examples were, however, almost the same. Therefore, it may be said that baroreflexive suppression of metabolism can contribute to the initiation of the fall in $T_{\mathrm{co} 1}$.

At $18^{\circ} \mathrm{C}$, the effect of central NT on heat loss was biphasic (Fig. 2). $H$ increased for the initial $20 \mathrm{~min}$ after an injection of 1.0 or $10.0 \mu \mathrm{g}$ of NT and significantly decreased thereafter. However, the decrease in $H$ may not directly indicate the decrease in cutaneous circulation, because the concomitant fall in body temperature decreased the temperature gradient from the deep body to the chamber wall. As an index of cutaneous blood flow, thermal conductance $(K)$ was calculated with an equation of $K=H /\left(T_{\mathrm{co1}}-T_{\mathrm{w}}\right)\left(T_{\mathrm{w}}\right.$ : temperature of chamber wall). The $K$ significantly increased from the resting values of $4.919 \pm 0.062$ or $5.059 \pm 0.149 \mathrm{~W} \cdot \mathrm{m}^{-2} \cdot{ }^{\circ} \mathrm{C}^{-1}$ after an injection of $0.1 \mu \mathrm{g}$ or $10.0 \mu \mathrm{g}$ of NT (Fig. 4). No significant fall in $K$ was observed within $60 \mathrm{~min}$ after the NT injection, which indicated rather a prolonged cutaneous vasodilation. At $28^{\circ} \mathrm{C}$, the $1.0 \mu \mathrm{g}$ of NT also produced a significant increase in $(R+C), E, H$, and $K$. These results suggest that the central NT may facilitate heat loss mechanisms in rats.

It is uncertain whether NT plays a role in the body temperature control mechanisms. CHANDrA et al. (1981) and LEE and Myers (1983) reported the poikilothermic effect of intraventricular NT in the rat. They observed NTinduced hypothermia below $22^{\circ} \mathrm{C}$ of ambient temperature and hyperthermia over

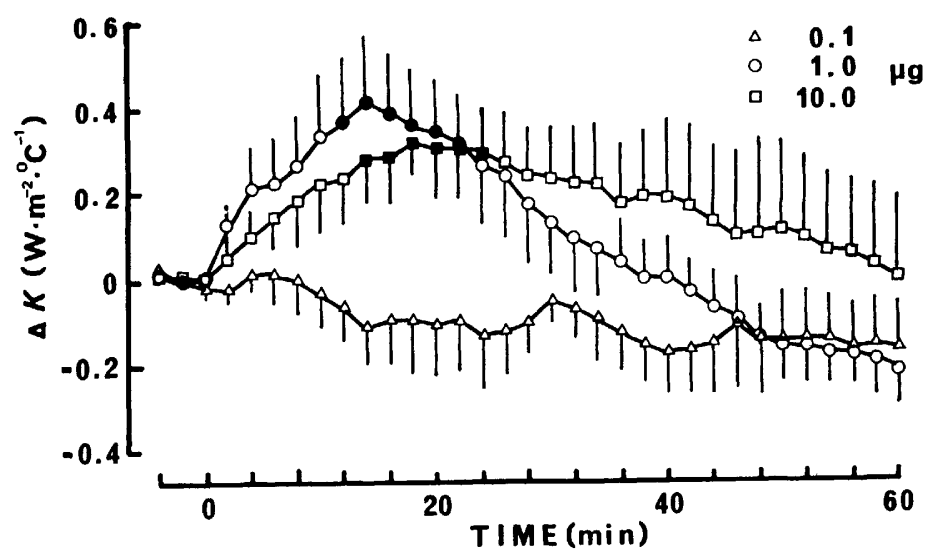

Fig. 4. Changes in conductance $(\Delta K)$ from resting values following various doses of NT injection into lateral ventricle. Values are means and vertical bars are S.E. Time 0 indicates the time of NT injection. Symbols are the same in Fig. 1. 
$30^{\circ} \mathrm{C}$ of $T_{\mathrm{a}}$. In the present study, body temperature response to NT at $T_{\mathrm{a}}$ of $28^{\circ} \mathrm{C}$ was various, hyperthermia occurred in 2 rats and hypothermia in 3 rats, although hypothermia was consistently observed following central NT at $18^{\circ} \mathrm{C}$. The ambient temperature of $28^{\circ} \mathrm{C}$ may not be high enough to produce NT-induced hyperthermia. Anyhow, this result seems to suggest the poikilothermic action of intraventricular NT rather than a thermolytic property. Furthermore, the fact that central NT increased both heat production and heat loss at $28^{\circ} \mathrm{C}$ seems to disagree with the idea that NT participates in the central mechanisms of body temperature regulation, and may support the conclusion of MorA et al. (1984) that NT does not play a role in the central mechanisms mediating the body temperature control.

In summary, the central NT produced pressor and hypothermic effects in conscious rats in a cool environment. However, the central pressor action of NT seemed to be less potent and the effect of arterial baroreflex may be the minimum in causing suppression of metabolism. The reductions of metabolism and cutaneous vasodilation were profound and persistent after central $\mathrm{NT}$ at $18^{\circ} \mathrm{C}$. On the contrary, both heat production and heat loss increased following NT at $28^{\circ} \mathrm{C}$. It seems doubtful that central NT acts in thermoregulatory centers in rats.

This study was supported by Grants-in-Aid for Scientific Research from the Ministry of Education, Science and Culture of Japan (58480119 and 58870016).

\section{REFERENCES}

Bissette, G., Luttinger, D., Mason, G. A., Hernandez, D. E., and Loosen, P. T. (1982) Neurotensin and thermoregulation. Ann. N.Y. Acad. Sci., 400: 268-282.

Bissette, G., Nemeroff, C. B., Loosen, P. T., Prange, A. J., Jr., and Lipton, M. A. (1976) Hypothermia and intolerance to cold induced by intracisternal administration of the hypothalamic peptide neurotensin. Nature, 262: 607-609.

Brown, D. R. and Miller, R. J. (1982) Neurotensin. Br. Med. Bull,, 38: 239-245.

Chandra, A., Chou, C., Chang, C., and LiN. M. T. (1981) Effects of intraventricular administration of neurotensin and somatostatin on thermoregulation in the rat. Neuropharmacology, 20: 715-718.

Hohtola, E., SaArela, S., and Hissa, R. (1980) Effect of blood pressure manipulations on shivering thermogenesis in the pigeon. Acta Physiol. Scand., 110: 277-283.

KRIEGER, E. M. (1964) Neurogenic hypertension in the rat. Circ. Res., 15: 511-521.

LEE, T. F. and MYERS, R. D. (1983) Analysis of the thermolytic action of ICV neurotensin in the rat at different ambient temperatures. Brain Res. Bull., 10: 661-665.

Martin, G. E., Bacino, C. B., and PApP, N. L. (1980) Hypothermia elicited by the intracerebral microinjection of neurotensin. Peptides, 1: 333-339.

Mora, F., LeE, T. F., and Myers, R. D. (1984) Is neurotensin in the brain involved in thermoregulation of the monkey? Peptides, 5: 125-128.

Nagasaka, T., Hirata, K., Sugano, Y., and Shibata, H. (1979) Heat balance during physical restraint in rats. Jpn. J. Physiol., 29: 383-392.

Nemeroff, C. B., Bissette, G., Manberg, P. J., Osbahr III, A. J., Breese, G. R., and Prange, A. J., Jr. (1980) Neurotensin-induced hypothermia: Evidence for an interaction with 
dopaminergic systems and the hypothalamic-pituitary-thyroid axis. Brain Res., 195: 69-84. Nemeroff, C. B., Bissette, G., Prange, A. J., Jr., Loosen, P. T., Barlow, T. S., and Lipton, M. A. (1977) Neurotensin: Central nervous system effects of a hypothalamic peptide. Brain Res., 128: 485-496.

NunomuRA, T. (1983) Baroreflex suppression of shivering and BAT thermogenesis following intraluminar inflation in the thoracic aorta in rats. J. J. Aerosp. Environ. Med., 20:57-65.

Rioux, F., Quirion, R., St-Pierre, S., Regoli, D., Jolicoeur, F. B., Belanger, F., and Barbeau, A. (1981) The hypotensive effect of centrally administered neurotensin in rats. Eur. J. Pharmacol., 69: 241-247.

Shibata, H. (1982) Baroreflex suppression of nonshivering thermogenesis in rats. Jpn. $J$. Physiol., 32: 937-944.

Shido, O., KIfUNE, A., and NAGASAKA, T. (1984) Baroreflexive suppression of heat production and fall in body temperature following peripheral administration of vasopressin in rats. Jpn. J. Physiol., 34: 397-406.

Shido, O., Kifune, A., and Nagasaka, T. (1985) Contributions of baroreceptor reflex to the hypothermic effect of intraventricular angiotensin II in rats. Jpn. J. Physiol., 35: 301-309.

Sumners, C., Phillips, M. I., and Richard, E. M. (1982) Central pressor action of neurotensin in conscious rats. Hypertension, 4: 888-893.

Wasserstrum, N. and Herd, J. A. (1977) Baroreflexive depression of oxygen consumption in the squirrel monkey at $10^{\circ} \mathrm{C}$. Am. J. Physiol., 232: $\mathrm{H} 451-\mathrm{H} 458$. 